\title{
国有企业服务型党组织建设的思考
}

孙佳

江苏长江水务股份有限公司

DOI:10.32629/er.v2i2.1683

[摘 要] 党的十九大报告明确提出: “要以提升组织力为重点, 突出政治功能, 把企业、农村、机关、学校、科研院所、街道 社区、社会组织等基层党组织建设成为宣传党的主张、贯彻党的决定、领导基层治理、团结动员群众、推动改革发展的坚强 战斗堡垒。”这是党中央对党的基层组织建设的新定位、新部署、新要求,为全面加强基层党组织建设指明了方向。

[关键词] 国有企业; 服务型党组织; 党建

\section{1 国有企业基层服务型党组织建设的意义}

国有企业基层党组织是党在企业中开展工作、增强凝聚 力和战斗力的重要基础, 承担着党的各项具体工作任务, 在 国有企业推动全面从严治党中具有重要地位和作用。当前, 中国特色社会主义进入了新时代, 党的建设也面临新的形势 任务。加强国有企业基层党组织建设, 就是要紧密结合国有 企业的特点, 始终做到坚持以提升组织力为重点、以突出政 治功能为核心、以加强党员队伍建设为抓手、以服务群众为 宗旨、以推动改革发展为己任, 切实发挥好基层党组织的战 斗堡垒作用和党员的先锋模范作用。

\section{2 国有企业基层服务型党组织建设面临的主要问题}

长期以来, 国有企业基层党组织始终坚持中央提出的 “围绕中心、服务大局” 的工作方针, 注重对企业生产经营、 改革发展以及党员、职工群众的管理和服务。随着企业面临 的市场环境、社会环境的变化和职工诉求的多样化, 企业党 组织如何适应新的形势还存在着一些问题和不足。一是重视 程度不够。认为基层党组织就是服务, 没必要再去刻意转型, 满足现状, 不思创新; 二是服务能力不够。面对企业改革、 发展, 存在怕越位、怕麻烦等心理, 被动地接受、跟随。三是 方法到位不够。平时的工作安排注重形式, 缺乏针对性。对 党员、群众关心的一些热点、难点问题调查、协调处理不力。 有的回避矛盾和问题, 怕得罪人, 等靠上级和行政组织解决。 对此, 笔者认为江苏长江水务股份有限公司第五党支部建设 基层服务型党组织的做法值得举荐。

\section{3 江苏长江水务股份有限公司第五党支部基层服务型}

\section{3. 结语}

总之, 在高中数学不等式教学中, 教师需要把握高考中 不等式考查的方向和重点, 做好总结解题方法、选取合适的 教学策略和突破教学中的重难点等方面的工作, 提高学生对 不等式知识的综合应用能力, 真正对数学知识做到触类旁 通。对于各高中来说, 数学教学是其教学内容中的一大难题, 而学好数学就需要有一个好的基础, 其中较为重要一个基础 版块就是不等式的学习。因此, 需要进行不等式学习的教学 探讨, 这样不仅能够提高学生对于数学的理解和提高数学高

\section{党组织建设的做法}

3.1 创新党建模式, 支部强基提质

近年来, 江苏长江水务股份有限公司第五党支部为适应 市场经济的要求, 始终坚持 “抓党建、聚合力、促发展、构 和谐” 的工作思路, 以党务工作研讨、党员职工培训、党建 活动交流和志愿服务活动为主要工作内容, 努力探索党组织 服务群众的新载体、党员教育的新路径、服务发展的新方向, 不断开拓新思路, 努力创新党建工作。由支部书记带领支部 下属部门的党员干部组成工作团队, 成立了吴书记工作室, 通过摸索和实践, 提炼出 “ $1+3$ ” 党建工作新模式, “ 1 ” 即一 个党支部; “ 3 ” 是三支队伍, 即: 书记工作室、发展智囊团、 便民服务队。书记工作室是由 5 名党员干部组成的一支能征 善战的团队, 他们深入、服务第一线, 面对面、硬碰硬地解决 棘手问题, 被职工誉为 “支撑大局的主心骨”。发展智囊团是 由党员和部分职工代表组成, 定期开展学习交流和工作研讨, 共同建言献策, 使党建工作与业务工作贴得更紧、靠得更实。 而便民服务队, 就是扬州市民非常熟悉的 “小李服务队”, 他们长年巡查在外, 走千家、访万户, 对客服咨询、供水维修、 质检测漏等工作做到尽心尽责, 自成立以来累计为用户解决 各种难题 15000 余起, 处理及时率达 99. 5\%, 满意率达 99\%以 上。在推进 “两学一做” 教育过程中, 通过开展 “三会一课”、 专业特色培训等学习教育活动, 培养了员工 “企业靠我发展、 我靠企业生存” 的理念。激励员工为企业发展努力贡献。充 分调动了广大员工的工作热情和积极性。2016 年春节前夕, 扬州遭受到百年一遇的寒潮, 有 3 万多只水表冻裂损坏, 平

\section{[参考文献]}

[1]孙艳芳. 高中数学不等式高考试题分析与教学策略 研究[J].中学课程辅导(教学研究),2015,(3): 37-37.

[2] 赵莉. 高中数学不等式高考试题分析与教学策略研究 [J].语数外学习(数学教育),2013,(11): 21 .

[3] 梁中军. 高中数学不等式高考试题分析与教学策略研 究[J].快乐阅读(下旬刊),2013,(12)：38-38. 
均每天接报 2000 余起。面对这么大的抢维修量, 为使广大居 民过个安乐祥和的春节, 支部进行紧急动员, 不分男女老少、 不分岗位不同、不分白天黑夜、冒着天寒地冻, 党员干部冲 在前, 全体员工齐跟上, 硬是在 12 天内完成了平时 1 年的工 作量, 充分发挥了党支部的战斗堡垒作用和党员干部的模范 表率作用。他们的瓣瓣心香与缕缕情丝, 让广大居民在泪泪 流淌的清泉中看到了党旗的熠熠生辉。

通过解读 “ $1+3$ ” 模式不难发现, 支部是龙头, 书记工作 室是抓手, 发展智囊团是风帆, 便民服务队是平台, 他们相互 依托, 相互补充, 共同支撑起江苏长江水务股份有限公司第 五党支部的 “红色引擎”。

\section{2 基层党建工作与企业文化相融合}

企业文化建设是国企基层党建工作的重要内容。随着国 企发展、改革的不断深化, 企业文化也提上了一定的高度。 第五支部在原有的基础上进一步完善党建园地, 改善党员的 学习环境。在建立健全支部图书室、电子书屋的同时, 还专 门配备了党建书籍、党报党刊、桌椅、电视等设施, 精心打 造属于党员自己的 “活动之家” , 使其成为党员职工学习交 流、提高能力素质的重要场所。组织党员干部积极参加 “支 部书记论坛”、“共产党员正家风”、“我是党课主讲人”、“迎 十九大、做合格党员”、“安全生产、职业健康” 知识竞赛、 “红色经典” 朗诵比赛、参观 “砥研奋进的扬州” 主题图片 展等。除此外, 支部还开展了 “两聚一高” 先锋行动、“做合 格党员、建过硬支部”、“亮身份、树形象、立足岗位作贡献” 等活动, 积极推选党员示范岗, 为每位党员配送党徽, 鼓励党 员树立 “一名党员, 一面旗帜” 的理念, 引导党员脚踏实地务 实干、立足岗位争贡献, 并以党小组为单位, 先后围绕 “旗帜 鲜明讲政治”、“我为创新、富民做什么”、“不忘初心、牢记 使命” 等主题开展大讨论, 增强了支部的战斗力和凝聚力。

3. 3 以民为本, 创新特色服务, 打造支部品牌

提升窗口形象。服务大厅严格执行城控集团“六个统一” 管理要求, 结合自身特点做好创新服务。进一步规范了服务 行为, 使每位员工都能适应岗位要求, 展示出企业良好的服 务形象, 公司举办了文明服务礼仪培训班, 来自窗口服务部 门及其他基层部门、下属公司、管理处室的 90 多名职工参 加了培训。先后邀请扬州市消协、扬州大学商贸旅游学院的 资深人士就消法常识、消费纠纷处理、公民责任意识和服务 礼仪等方面开设了讲座, 不断提高服务水平。同时开展了 “送 培训进基层” 工作。增加了受训的基层部门, 并根据部门实 际, 对培训的课程设置和培训内容进行了适当调整, 新增了 两个授课部门, 以进一步提高培训的针对性和实效性。培训 涉及泵站机组设备维护、生产工艺、应急预案、水质检测、 会计准则及财务、工程造价、客户服务等专业技术知识以及 劳资知识、人事管理制度等方面的内容。目前，“送培训进 基层” 第一轮培训工作已经展开, 各职能处室结合授课内容, 认真做好准备, 主动与基层部门对接, 确保培训任务顺利完 成。同时大厅还增设 3 个一卡通收费窗口, 减少用户等候时
间。窗口引导员设立双人双岗, 宝带大厅全年提前半小时开 门, 加设 “手机充电站” , 大大方便了用户。

除做好本职工作外, 为了进一步服务广大居民, 职工积极 参加志愿者服务活动。志愿者们每月走进社区开展服务活动, 宣讲供用水常识、开展 “节水” 知识讲座、以 “访民情、释民 惑、汇民智、解民忧、惠民生” 为主题, 开展 “大走访大排查” 活动, 切实解决影响群众用水的实际问题。积极参与了扬州市 区 11 个街道的社区座谈会, 与 95 名社区代表进行了面对面的 对话, 并走访慰问了 22 个困难家庭, 全面了解并解决居民用户 存在的用水困难以及对供水服务的需求。目前已落实解决大唐 世家小高层移交改造、朝阳南苑水表出户等 38 项社区及用户 反映的问题。2017 年走进天顺社区、兰苑社区、个园社区、 冯庄社区、教场社区等 20 个社区, 发放用水宣传册 4000 余份、 水表保温棉 15000 余张, 提供现场咨询 2200 余次、免费便民维 修用水故障 480 余起。志愿者队伍还积极做好特困帮扶等延伸 服务工作, 与个园社区形成结对帮扶关系, 确定社区两户困难 家庭作为帮扶对象。定期开展多种形式的慰问、党员定向捐款 等活动。向公司申请减免一些费用, 以解决他们的实际困难。 使他们实实在在地感受到党的温暖。

2018 年 6 月 15 日, 江苏省国资委举办的全省国有企业 党建强基提质工程创新案例表彰会在南京召开, 江苏长江水 务股份有限公司第五党支部 “ $1+3$ ” 党建模式荣获全省国有 企业党建强基提质工程创新案例一等奖。

\section{4 推进基层服务型党组织建设的路径}

江苏长江水务股份有限公司第五党支部基层服务型党 组织建设的实践告诉我们, 推进服务型党组织建设是一项长 期、复杂的工程, 不仅需要加强自身建设, 还需要充分利用自 身的服务资源和凭借自身的核心领导地位㲠动社会上的各 种服务资源, 汇集各方力量, 上下联动, 左右联动, 构建多层 次、全方位的服务型党组织体系。加强对党员干部的管理教 育培训, 提高服务意识和服务能力。以群众路线教育实践活 动为载体, 完善考评反馈制度, 用硬性的标尺衡量建设成效。 完善监管机制, 增强制度的权威性, 确保党的先进性和纯洁 性, 从而达到共同推进基层服务型党组织建设, 最大程度地 实现广大人民群众的根本利益。

综上所述, 国有企业基层服务型党组织建设是党对社会 发展过程中产生诸多问题的积极回应。需要党组织发挥自身 的核心领导作用, 汇集各方力量, 加强自身建设, 整合党内外 资源, 辅之以制度保障, 推进基层服务型党组织建设的成效 就会越来越显著, 就会为群众提供更多、更高质量的服务。

\section{[参考文献]}

[1]孟飞,徐媛媛.推进国有企业党建工作创新的路径思 考[J].中共山西省委党校学报,2017,40(02):109-113.

[2]张太星.新时期区属国企服务型党组织建设经验及启 示——上海市徐汇区为例 [J]. 学理论,2016(04):175-176.

[3]全书林.浅谈基层医院党建工作的加强和改进[J].办 公室业务,2018(07):16+25. 